\title{
An Investigation into the Recycling of Gas Vesicle Protein Derived from Collapsed Gas Vesicles
}

\author{
By P. K. HAYES AND A. E. WALSBY* \\ Department of Botany, University of Bristol, Woodland Road, Bristol BS8 1UG, UK
}

(Received 30 December 1983; revised 1 March 1984)

Gas vesicle protein may account for more than $6 \%$ of the cell dry weight and over $10 \%$ of the total cell protein in the planktonic cyanobacterium Anabaena flos-aquae. The gas vesicles collapsed by rising cell turgor pressure during buoyancy regulation can therefore represent a significant protein pool within this organism. We have looked for evidence of gas vesicle protein recycling. Gas vesicles were isolated from cells of $A$. flos-aquae that had been pressurized and then cultured in a radioactively labelled medium. The new gas vesicles that formed were less highly labelled than the new vesicles formed in cells from a second culture that had not been pressurized. The results suggest that the collapsed gas vesicles are disaggregated and that the constituent gas vesicle protein is reassembled into new gas vesicles. Proof of this will require experiments using in vitro assembly systems.

\section{INTRODUCTION}

The walls of gas vesicles, which comprise the gas vacuoles of cyanobacteria and other planktonic micro-organisms, are composed of a single type of protein, gas vesicle protein (GVP) Walker \& Walsby (1983). The gas vesicles are hollow structures of low density and they provide buoyancy. Some planktonic cyanobacteria, such as Anabaena flos-aquae, regulate their buoyancy by controlling the volume occupied by intact gas vesicles. They do this by accumulating new gas vesicles under low light intensity and collapsing existing intact gas vesicles under high light intensity. The collapse of gas vesicles is brought about by a rise in cell turgor pressure generated partly by an increase in the concentration of organic products of photosynthesis (Dinsdale \& Walsby, 1972; Grant \& Walsby, 1977) and partly by light-stimulated accumulation of potassium ions from the suspending medium (Allison \& Walsby, 1981).

GVP is one of the more abundant proteins found in extracts of A. flos-aquae (Walsby, 1977), and may account for over $10 \%$ of the total protein. When the cyanobacterium is transferred from conditions of low to high light intensity, over $60 \%$ of those gas vesicles initially present may be collapsed (Oliver \& Walsby, 1984). We have examined the idea that the GVP from these collapsed gas vesicles is recycled. There are several features of gas vesicles that facilitate such an investigation into the turnover of their component molecules. Firstly, it is possible to isolate intact gas vesicles in a highly purified form (Buckland \& Walsby, 1971). Secondly, all of the gas vesicles present in a cell may be collapsed by application of pressure; none of the collapsed gas vesicles are subsequently isolated with the intact structures that are recovered by centrifugally accelerated flotation. It is therefore possible to follow the incorporation of label into the structures from a precisely known time. Thirdly, the fact that there is only one type of constituent molecule, GVP, greatly simplifies interpretation of the results.

We report here the results of ${ }^{14} \mathrm{C}$-labelling experiments which support the idea that GVP from collapsed gas vesicles is recycled into new intact gas vesicles.

Abbreviations: GVP, gas vesicle protein; PSOD, pressure-sensitive optical density. 


\section{METHODS}

Organism and culture. The investigation was carried out with the gas-vacuolate strain of Anabaena flos-aquae (1304/13f, Culture Centre for Algae and Protozoa, Cambridge, UK) (Booker \& Walsby, 1979). It was grown in medium B (without nitrate) described by Armstrong et al. (1983).

Conditions for ${ }^{14} \mathrm{C}$-labelling. A culture, grown for $10 \mathrm{~d}$ at $20^{\circ} \mathrm{C}$ and under an incident radiant flux of $30 \mu \mathrm{E} \mathrm{m} \mathrm{m}^{-2}$ $\mathrm{s}^{-1}$, was diluted to 2.51 with fresh, sterile medium. Samples were taken for the determination of total inorganic carbon (Golterman et al., 1978), dry weight, total cell carbon and gas vesicle gas space volume. Two 1-1 volumes of culture, one of which had been pressurized (13 bar) to collapse any existing gas vesicles, were sealed into 2-1 capacity Buchner flasks and flushed with $\mathrm{N}_{2}$, so that the oxygen subsequently produced during photosynthesis would not reach toxic levels. The pressure in the overlying gas space in each flask was then reduced to $0 \cdot 8$ bar. Each flask was then supplied with ${ }^{14} \mathrm{C}$-labelled $\mathrm{NaHCO}_{3}$ of known specific radioactivity (given in Results and Discussion) and in sufficient quantity $(\approx 100 \mathrm{mg} \mathrm{C})$ to allow growth without carbon limitation. These cultures were then incubated at $20^{\circ} \mathrm{C}$ and $20 \mu \mathrm{E} \mathrm{m}^{-2} \mathrm{~s}^{-1}$ incident radiant flux for $5 \mathrm{~d}$. At the end of the labelling period, samples were taken for the determination of dry weight, total cell carbon, gas vesicle gas space volume and the amount of radioactivity in the cells. The remaining material was used for gas vesicle isolation.

Dry weight determination. Five replicate $10 \mathrm{ml}$ samples of the culture were pressurized at 13 bar and centrifuged at an acceleration of $14700 \mathrm{~m} \mathrm{~s}^{-2}$ for $15 \mathrm{~min}$. The supernatant was removed and the pellet resuspended in fresh medium and recentrifuged. The resedimented material was suspended in a total volume of $0.5 \mathrm{ml}$ with fresh culture medium, transferred to a pre-weighed aluminium cup, dried at $60^{\circ} \mathrm{C}$ for $12 \mathrm{~h}$, and then $100^{\circ} \mathrm{C}$ for $24 \mathrm{~h}$ before weighing on a Cahn electrobalance. The dry weights were corrected for the salt content of the fresh medium, which was $0.02 \mathrm{mg}$ in $0.5 \mathrm{ml}$, compared with 0.3 to $1.0 \mathrm{mg}$ of dried organic material.

Determination of radioactivity. Samples $(1 \mathrm{ml})$ of the $A$. flos-aquae culture were mixed with $5 \mathrm{ml}$ of a mixture of methanol and acetic acid $(9: 1, \mathrm{v} / \mathrm{v})$ and evaporated to $1 \mathrm{ml}$ under a stream of air. To the concentrate was added $10 \mathrm{ml}$ of Scintran Cocktail T (BDH). Up to $40 \mu \mathrm{l}$ of radioactively labelled purified gas vesicles were mixed directly with $10 \mathrm{ml}$ of the same scintillation cocktail. The radioactivity of the samples was then determined in a Searle Analytical Isocap 300 scintillation counter and corrected for counting efficiency by the channels ratio method.

Determination of gas vesicle gas space volume. The volume of gas vesicle gas space in samples of the cyanobacterial culture was determined directly from the irreversible contraction of the meniscus in the compression tube apparatus described by Walsby (1982). Triplicate measurements were made. The only modification was a water jacket for the compression tube which gave improved thermal stability. From the measurements of Walsby \& Armstrong (1979) it is known that a contraction of $1 \mathrm{nl}$ indicates the presence of gas vesicles containing $0 \cdot 130 \mu \mathrm{g}$ GVP.

Isolation of gas vesicles. The Anabaena filaments were concentrated by filtering onto a $3 \mu \mathrm{m}$ pore size Nucleopore filter. Intact gas vesicles were then isolated from cells lysed in $1.4 \mathrm{M}$-sucrose followed by centrifugally accelerated flotation, as described by Walsby \& Buckland (1969), and detergent washing (Walsby \& Armstrong, 1979). The concentration of GVP in the final purified preparation was estimated from readings of pressure-sensitive optical density (PSOD) at a wavelength of $500 \mathrm{~nm}$ and a path length of $1 \mathrm{~cm}$ : Walsby \& Armstrong (1979) have shown that a suspension of intact gas vesicles giving a PSOD of 1.0 contains $47.9 \mu \mathrm{g} \mathrm{GVP} \mathrm{ml}{ }^{-1}$; this is equivalent to $25.5 \mu \mathrm{g} \mathrm{GVP}$ carbon $\mathrm{ml}^{-1}$ because the carbon content calculated from the known amino acid composition (Walker \& Walsby, 1983) is $53.27 \%$ of the dry weight of GVP. The radioactivity of the purified gas vesicles was determined as above and from this the specific activity of the carbon in the GVP was calculated.

Rate of gas vesicle reformation. Growth in two $600 \mathrm{ml}$ cultures of $A$. flos-aquae, maintained at $20^{\circ} \mathrm{C}$ and 9 to $9.8 \mu \mathrm{E} \mathrm{m}^{-2} \mathrm{~s}^{-1}$ mean irradiance, was monitored over a $3 \mathrm{~d}$ period. Samples were removed from each culture for the determination of dry weight and gas vesicle volume at the start of the incubation period and again after $1,1 \cdot 25$, 2 and $3 \mathrm{~d}$. The gas vesicles present in one of the cultures were collapsed, by application of pressure, immediately after the sample at day 1 had been taken.

Determination of total cell carbon. Samples of $A$. flos-aquae were prepared by centrifugation as described above (see section on dry weight determination). After freeze drying, the carbon content of the pelleted material was measured using a Perkin Elmer $240 \mathrm{CHN}$ analyser.

\section{RESULTS AND DISCUSSION}

The overall changes in dry weight, protein and gas vesicle content of $A$. flos-aquae cells that occurred on transfer from culture $A$, grown on unlabelled bicarbonate, to cultures $B$ and $C$, grown for $5 \mathrm{~d}$ on labelled bicarbonate, are summarized in Table 1. It is seen that there was no significant difference in cell growth in cultures $B$ and $C$, as estimated from the change in dry weight, but the gas vesicle content of culture $C$, which had been pressurized to collapse existing intact gas vesicles, had increased more than that in culture $B$, which had not been pressurized. 
Table 1. Growth and gas vesicle formation in Anabaena flos-aquae

Values are given for samples collected at the start of the incubation period $(A)$, from a sub-culture after $5 \mathrm{~d}$ growth in the presence of $\left[{ }^{14} \mathrm{C}\right]$ bicarbonate $(B)$, and from another sub-culture in which existing gas vesicles were collapsed prior to incubation in the presence of $\left[{ }^{14} \mathrm{C}\right]$ bicarbonate for $5 \mathrm{~d}(C)$.

\begin{tabular}{|c|c|c|c|c|c|c|c|}
\hline \multicolumn{6}{|c|}{ Quantities (ml culture $)^{-1}(95 \%$ confidence limits in parentheses) } & \multirow{2}{*}{\multicolumn{2}{|c|}{$\begin{array}{l}\text { Increase relative } \\
\text { to initial culture } \\
\text { over } 5 \mathrm{~d}(\%)\end{array}$}} \\
\hline & & \multicolumn{2}{|c|}{$\begin{array}{l}\text { Final culture after } 5 \mathrm{~d} \\
\text { growth }\end{array}$} & \multicolumn{2}{|c|}{ Increase in quantities } & & \\
\hline Measurement & $\begin{array}{l}\text { Initial } \\
\text { culture } \\
(A)\end{array}$ & $\begin{array}{l}\text { Without } \\
\text { collapsing } \\
\text { vesicles } \\
(B)\end{array}$ & $\begin{array}{l}\text { After } \\
\text { collapsing } \\
\text { vesicles } \\
\text { (C) }\end{array}$ & $\begin{array}{l}\text { Without } \\
\text { collapsing } \\
\text { vesicles } \\
(B-A)\end{array}$ & $\begin{array}{l}\text { After } \\
\text { collapsing } \\
\text { vesicles } \\
(C-A)\end{array}$ & $\begin{array}{l}\text { Without } \\
\text { collapsing } \\
\text { vesicles }\end{array}$ & $\begin{array}{c}\text { After } \\
\text { collapsin } \\
\text { vesicles }\end{array}$ \\
\hline $\begin{array}{l}\text { Gas vesicle } \\
\text { volume (nl) } \\
\text { GVP in intact }\end{array}$ & $16 \cdot 40( \pm 2 \cdot 78)$ & $40 \cdot 24( \pm 0)$ & $28 \cdot 69( \pm 2 \cdot 77)$ & $23 \cdot 84$ & $28 \cdot 69( \pm 2 \cdot 77)^{*}$ & 145 & 175 \\
\hline $\begin{array}{l}\text { gas vesicles } \nmid \\
(\mu \mathrm{g}) \\
\text { Cell dry }\end{array}$ & $2 \cdot 14( \pm 0 \cdot 36)$ & $5 \cdot 25( \pm 0)$ & $3 \cdot 74( \pm 0 \cdot 36)$ & $3 \cdot 11$ & $3 \cdot 74( \pm 0.36)^{*}$ & 145 & 175 \\
\hline $\begin{array}{l}\text { weight }(\mu \mathrm{g}) \\
\text { Cell protein }\end{array}$ & $50 \cdot 5( \pm 5 \cdot 51)$ & $91.8(7.96)$ & $89 \cdot 8( \pm 6 \cdot 02)$ & $41 \cdot 3$ & $39 \cdot 3$ & 82 & 78 \\
\hline $\begin{array}{l}(\mu \mathrm{g}) \\
\text { GVP in intact } \\
\text { gas vesicles: } \\
\text { cell protein }\end{array}$ & $27 \cdot 4$ & $49 \cdot 7$ & $48 \cdot 7$ & $22 \cdot 3$ & $21 \cdot 3$ & 82 & 78 \\
\hline$(\%)$ & $7 \cdot 7$ & $10 \cdot 6$ & $7 \cdot 7$ & 13.9 & $17 \cdot 6$ & - & - \\
\hline
\end{tabular}

* All gas vesicles were formed after the collapse of existing gas vesicles in the initial culture. The total gas vesicle content is therefore equivalent to the net increase in gas vacuolation during the labelling period.

+ Calculated from gas vesicle volume.

$\ddagger$ Estimated from that proportion of the dry weight accounted for by protein in cells of $A$. flos-aquae grown under conditions similar to those used in the present study (Oliver \& Walsby, 1984).

The protein in the gas vesicles accounted for nearly $6 \%$ of the total cell dry weight, and over $10 \%$ of the total cell protein in culture $B$, and the new GVP in the extra gas vesicles synthesized represented nearly $14 \%$ of the new total protein accumulated during $5 \mathrm{~d}$ growth. This relative increase in gas vesicle content is probably a response to the decreasing mean light intensity within the growing culture (Van Liere \& Walsby, 1982). The GVP in new intact gas vesicles represented an even larger proportion of new protein in culture $C$ but as discussed below some of this GVP may not have been newly synthesized.

At the end of the period of growth on ${ }^{14} \mathrm{C}$-labelled bicarbonate the radioactivity of the cyanobacteria was measured and it was calculated that the specific activity of the extra carbon incorporated in this period did not differ significantly from the specific activity of the carbon supplied in either culture, $B$ or $C$. The results of other analyses performed on these cultures are given in Table 2, and from the values obtained it is possible to calculate the proportion of labelled and unlabelled carbon in the gas vesicles present after each treatment.

The specific activity of the carbon in the gas vesicles isolated from culture $B[39.58 \mathrm{~Bq}(\mu \mathrm{g}$ C) $\left.{ }^{-1}\right]$ was found to be 0.655 times that of the specific activity supplied $\left[60.38 \mathrm{~Bq}(\mu \mathrm{g} \mathrm{C})^{-1}\right]$. Thus of the $5.25 \mu \mathrm{g} \mathrm{GVP}$ present per ml of culture $65.5 \%$, or $3.44 \mu \mathrm{g}$, had formed from labelled carbon fixed after resuspending the Anabaena in ${ }^{14} \mathrm{C}$-labelled medium. This corresponds fairly closely with the net increase in gas vesicles determined by the compression tube measurements, $3 \cdot 11 \mu \mathrm{g}$ per $\mathrm{ml}$ of culture. (The small difference between these estimates, $0.33 \mu \mathrm{g} \mathrm{GVP}$ per ml, may indicate that a small proportion of the original unlabelled gas vesicles was lost by spontaneous collapse.) Hence, none of the new GVP accumulated in this culture had been synthesized from unlabelled carbon.

In culture $C, 3.74 \mu \mathrm{g}$ of gas vesicles were formed per $\mathrm{ml}$ of culture after pressurizing and subsequent transfer to ${ }^{14} \mathrm{C}$-labelled medium. If all of the carbon they contained had come from 
Table 2. Determination of the amounts of labelled and unlabelled GVP that had formed in the presence of ${ }^{14} \mathrm{C}$-labelled bicarbonate

(A) Values from samples taken immediately prior to ${ }^{14} \mathrm{C}$ addition. $(B)$ Values obtained from a culture where the gas vesicles were left intact at the time of the ${ }^{14} \mathrm{C}$ addition. $(C)$ Values obtained from a culture where the gas vesicles were collapsed at the time of ${ }^{14} \mathrm{C}$ addition. Where applicable the $95 \%$ confidence limits are given in parentheses.

Measurement*

(a) Specific activity of supplied carbon $\left(\mathrm{Bq} \mu \mathrm{g}^{-1}\right)$

(b) Weight of GVP in intact gas vesicles $(\mu \mathrm{g})$

(c) Weight of GVP-carbon in intact gas vesicles $(\mu \mathrm{g})$

(d) PSOD of original gas vesicle suspension

(e) Concn of GVP-carbon in isolated gas vesicle suspension $\left(\mu \mathrm{g} \mu \mathrm{l}^{-1}\right)$

$(f)$ Radioactivity of gas vesicle suspension $\left(\mathrm{Bq} \mu \mathrm{l}^{-1}\right.$ )

(g) Specific activity of carbon in GVP $\left(B q \mu \mathrm{g}^{-1}\right)$

(h) Weight of ${ }^{14} \mathrm{C}$-labelled GVP $(\mu \mathrm{g})$

(i) Weight of unlabelled GVP $(\mu \mathrm{g})$

$A$
nil
$2 \cdot 14( \pm 0 \cdot 36)$
$1 \cdot 14( \pm 0 \cdot 19)$
ND

ND
ND
ND
nil
$2 \cdot 14$

ND, Not determined.

* The values given in $b, c, h$ and $i$ are quantities per $\mathrm{ml}$ of culture. Values were calculated as follows. (b) From Table 1. (c) $b \times 0.5327 \mathrm{~g} \mathrm{C}(\mathrm{g} \mathrm{GVP})^{-1}$. (d) Calculated from reading of original suspension diluted 166.7 times in a $1 \mathrm{~cm}$ pathlength cuvette. $(e) d \times 25 \cdot 5 \mu \mathrm{g} \mathrm{GVP-carbon} \mathrm{ml}^{-1}$.

$$
\begin{gathered}
60 \cdot 38 \\
5 \cdot 25( \pm 0) \\
2 \cdot 79( \pm 0) \\
25 \cdot 5
\end{gathered}
$$

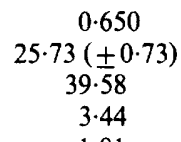

$1 \cdot 81$
C

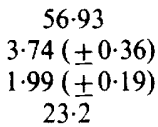

0.591
$21 \cdot 70( \pm 0 \cdot 72)$
$36 \cdot 72$
2.41
1.33 (g) $f \div e$.

(h) $b \times g \div a$.

(i) $b-h$.

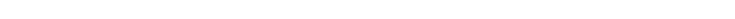

carbon fixed after transfer it would have had the same specific activity as the carbon supplied, i.e. $56.93 \mathrm{~Bq}(\mu \mathrm{g} \mathrm{C})^{-1}$. In fact the specific activity of the GVP carbon was only $36.72 \mathrm{~Bq}(\mu \mathrm{g}$ C) ${ }^{-1}$, which is 0.645 of that supplied. This indicates that about $35 \%$ (or $1.33 \mu \mathrm{g} \mathrm{GVP}$ per $\mathrm{ml}$ of culture) of these new gas vesicles had been formed from unlabelled carbon fixed before pressurizing and transfer. The accumulation of unlabelled GVP in the new gas vesicles could be explained in a number of ways.

(I) Organic carbon recycled from protein turnover. It is known that in other bacteria many proteins have a limited life-time and are broken down into amino acids by proteases (Pine, 1972). In theory, the unlabelled protein in the new gas vesicles of the pressurized culture could have been synthesized partly from such breakdown products. However, if this had occurred the new gas vesicles in the unpressurized culture should also have contained unlabelled protein. Since they did not this explanation is unlikely to be correct. The same considerations apply to carbon recycled from other reserves, such as glycogen.

(2) Recycling of GVP via proteolysis and resynthesis. The amount of unlabelled GVP present in the new gas vesicles formed after pressure treatment $\left(1.33 \mu \mathrm{g} \mathrm{ml}^{-1}\right)$ was equivalent to $62 \%$ of the (unlabelled) GVP in the gas vesicles collapsed by pressure $\left(2.14 \mu \mathrm{g} \mathrm{ml}^{-1}\right)$ and hence all of it could have come from the collapsed vesicles. However, if the GVP from collapsed gas vesicles had been first hydrolysed into its constituent amino acids there is no obvious reason why it should have been used to synthesize new GVP in preference to other proteins. The proportion that would enter GVP would have been no more than the proportion that GVP formed of the total protein being synthesized, i.e. only $17.6 \%$ of the $2.14 \mu \mathrm{g} \mathrm{ml}^{-1}$ (see Table 1 ), or $0.39 \mu \mathrm{g} \mathrm{GVP}$ per $\mathrm{ml}$ of culture, substantially less than the $1.33 \mu \mathrm{g}$ of unlabelled GVP observed. These considerations are made with the assumption that there had been a steady rate of cell growth and gas vesicle production.

A higher proportion of unlabelled amino acids entering new gas vesicles could in theory have resulted from an increased rate of GVP synthesis coinciding with a sudden release of amino acids from the unlabelled collapsed gas vesicles. In a separate experiment we followed the time course of gas vesicle production in pressurized and unpressurized samples of a culture. We again demonstrated a higher rate of gas vesicle production after application of pressure but that increased rate was sustained over $2 \mathrm{~d}$ and was not restricted to a short period of time (see Fig. 1). The rate of cell growth showed no significant change over the same period in either sample. Again, there is no support for this explanation from these results. 


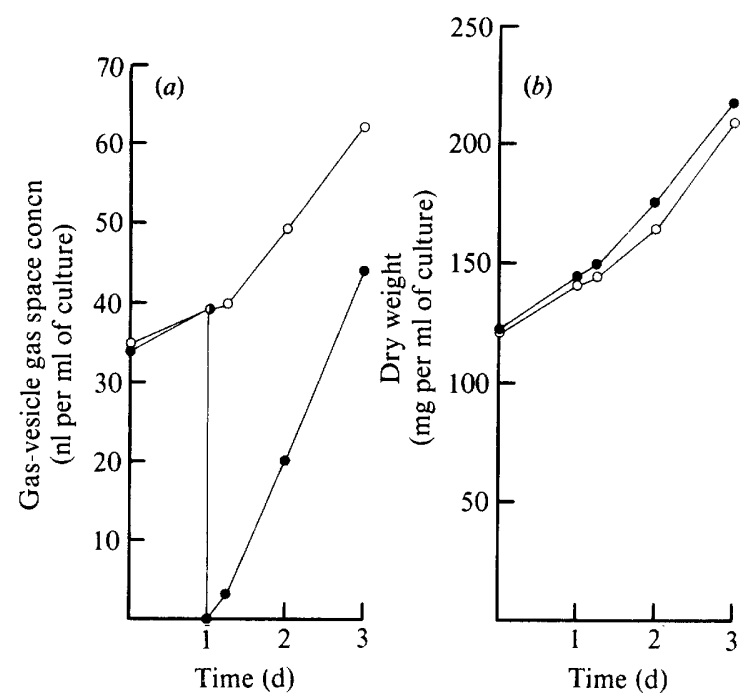

Fig. 1. Growth and gas vesicle accumulation in Anabaena flos-aquae. (a) Change in gas vesicle volume, and $(b)$ change in the dry weight of cells per $\mathrm{ml}$ of culture. Culture pressurized on day 1 to collapse existing gas vesicles; $O$, control incubation (without pressure).

(3) Recycling of intact GVP molecules. A third possibility is that GVP from the collapsed gas vesicles becomes reassembled into new intact gas vesicles. This would be entirely consistent with the high proportion of unlabelled GVP found in the new gas vesicles of pressure treated cells and provides the most likely explanation for the observed labelling pattern.

The recycling of GVP indicated by this experiment was not expected. We therefore performed three further experiments of similar design. In each case we observed that unlabelled GVP was incorporated in the new gas vesicles assembled after application of pressure; in the four experiments unlabelled GVP accounted for a mean value of $43.6 \%$ of the new gas vesicles formed. In all of the experiments it was also observed that the unlabelled GVP incorporated in new vesicles was equivalent to a substantial percentage (mean value $61.9 \%$ ) of the GVP in the collapsed gas vesicles and that the amount of gas vesicles assembled in the pressurized culture exceeded that in the unpressurized one (by a mean value of $38.8 \%$ ) after $5 \mathrm{~d}$. We also performed a further experiment in which the cells were grown initially in the presence of ${ }^{14} \mathrm{C}$-labelled medium and then resuspended in unlabelled medium. In this experiment ${ }^{14} \mathrm{C}$-labelled carbon was recycled into the new gas vesicles that formed in similar proportions to the unlabelled carbon recycled in the experiments described above. Together these experiments provide strong evidence for the unexpected recycling of undegraded GVP from collapsed gas vesicles into new intact ones.

If GVP is recycled without degradation it is likely that this would proceed by disaggregation of the protein molecules followed by their reaggregation. Collapsed gas vesicles cannot be reinflated with gas because they are far too permeable to gases (Walsby, 1969) and they are anyway damaged by the separation of their conical end caps (Walsby, 1971). Lehmann \& Jost (1971) demonstrated that following collapse of gas vesicles by pressure the new ones that formed showed the same gradual elongation from biconical initials that characterize gas vesicles forming by de novo assembly (Waaland \& Branton, 1969).

In order to prove the recycling via disaggregation and assembly it might be necessary to perform experiments with in vitro systems of gas vesicle assembly supplied with labelled collapsed gas vesicles. Lehmann \& Jost (1972) reported a short-lived assembly system from another cyanobacterium, Microcystis aeruginosa. Special factors would be necessary because isolated and purified gas vesicles do not reassemble spontaneously after collapse (Walsby, 1971). 
Reassembly of GVP from collapsed gas vesicles would be energetically more favourable than proteolysis followed by resynthesis, and there are precedents for such reassembly systems, e.g. microtubules (Snyder \& McIntosh, 1976; Hill \& Kirschner, 1982) and coated vesicles (Pearse, 1980).

This work was supported by a grant from the Science and Engineering Research Council. We are grateful to $\mathrm{Mr}$ M. West and M. D. Davies for analysis of organic carbon, and Professor Daniel Branton for many useful discussions on the recycling of gas vesicle protein.

\section{REFERENCES}

ALLison, E. M. \& WaLsBY, A. E. (1981). The role of potassium in the control of turgor pressure in a gas vacuolate blue-green alga. Journal of Experimental Botany 32, 241-249.

armstrong, R. E., Hayes, P. K. \& Walsby, A. E. (1983). Gas vacuole formation in hormogonia of Nostoc muscorum. Journal of General Microbiology 128, 263-270.

BOoKER, M. J. \& WalsBY, A. E. (1979). The relative form resistance of straight and helical blue-green algal filaments. British Phycological Journal 14, 141150.

BuCKLAND, B. \& WaLSBY, A. E. (1971). A study of the strength and stability of gas vesicles isolated from a blue-green alga. Archiv für Mikrobiologie 79, 327337.

Dinsdale, M. T. \& Walsby, A. E. (1972). The interrelations of cell turgor pressure, gas-vacuolation, and buoyancy in a blue-green alga. Journal of Experimental Botany 23, 561-570.

Golterman, H. L., Clymo, R. S. \& Ohnstad, M. A. M. (1978). Methods for Physical and Chemical Analysis of Fresh Waters, 2nd edn. IBP Handbook No. 8. Oxford: Blackwell Scientific Publications.

Grant, N. G. \& Walsby, A. E. (1977). The contribution of photosynthate to turgor pressure rise in the planktonic blue-green alga Anabaena flosaquae. Journal of Experimental Botany 28, 409-415.

HILL, T. L. \& KIRSCHNER, M. W. (1982). Bioenergetics and kinetics of microtubule and actin filament assembly-disassembly. International Review of Cytology 78, 1-125.

LemmanN, H. \& Jost, M. (1971). Kinetics of the assembly of gas vacuoles in the blue-green alga Microcystis aeruginosa Kuetz. emend. Elenkin. Archiv für Mikrobiologie 79, 59-68.

LehmanN, H. \& Jost, M. (1972). Assembly of gas vacuoles in a cell-free system of the blue-green alga Mic:ocystis aeruginosa Kuetz. emend. Elenkin. Archiv für Mikrobiologie 81, 100-102.

OLIVER, R. L. \& WALSBY, A. E. (1984). Direct evidence for the role of light mediated gas vesicle collapse in the buoyancy regulation of Anabaena flos-aquae (cyanobacteria). Limnology and Oceanography (in the Press).

Pearse, B. M. F. (1980). Coated vesicles. Trends in Biochemical Sciences 5, 131-134.

PINE, M. J. (1972). Turnover of intracellular proteins. Annual Review of Microbiology 26, 103-126.

SNYDER, J. A. \& MCINTOSH, J. R. (1976). Biochemistry and physiology of microtubules. Annual Review of Biochemistry 45, 699-720.

VAN LIERE, L. \& WALSBY, A. E. (1982). Interactions of cyanobacteria with light. In The Biology of the Cyanobacteria, pp. 9-45. Edited by N. G. Carr \& B. A. Whitton. Oxford: Blackwell Scientific Publications.

WAaland, J. R. \& BRANTON, D. (1969). Gas vacuole development in a blue-green alga. Science 163, 13391341 .

WALKer, J. E. \& Walsby, A. E. (1983). Molecular weight of gas vesicle protein from the planktonic cyanobacterium Anabaena flos-aquae and implications for structure of the vesicle. Biochemical Journal 209, 809-815.

WALSBY, A. E. (1969). The permeability of blue-green algal gas-vacuole membranes to gas. Proceedings of the Royal Society B173, 235-255.

WALSBY, A. E. (1971). The pressure relationships of gas vacuoles. Proceedings of the Royal Society B178, 301326.

WALSBY, A. E. (1977). Absence of gas vesicle protein in a mutant of Anabaena flos-aquae. Archiv für Mikrobiologie 114, 167-170.

WALSBY, A. E. (1982). The elastic compressibility of gas vesicles. Proceedings of the Royal Society B216, 353-368.

WaLSBY, A. E. \& ARmSTrong, R. E. (1979). Average thickness of the gas vesicle wall in Anabaena flosaquae. Journal of Molecular Biology 129, 279-285.

WALSBY, A. E. \& BuCKLAND, B. (1969). Isolation and purification of intact gas vesicles from a blue-green alga. Nature, London 224, 716-717. 